\title{
ECONOMIC GLOBALIZATION BETWEEN EXPANSION AND LIMITS. SOME CONCEPTUAL CONSIDERATIONS
}

\author{
Cătălin Postelnicu \\ Department of Economics, Faculty of Economics and Business Administration, \\ Babes-Bolyai University, Cluj-Napoca, Romania \\ catalin.postelnicu@econ.ubbcluj.ro
}

\begin{abstract}
This article tries to answer to the question if the actual wave of globalization may be considered viable under the conditions of increasing inequalities, poverty, environmental degradation, behavioral rules of international markets and other important factors. The author considers that the last wave of globalization cannot be fully feasible on the long run, based upon several arguments offered by the specialized studies in the field and from important data evidence reported by some international economic organizations. By definition, the globalization of the economy reflects a reality that has various meanings. Being focused on the free movement of goods and capital, this phenomenon does not necessarily imply a political globalization, although it cannot be completely detached from this field. That is why, from the beginning, it has offered the possibility to large multinational corporations to operate everywhere in the world, thanks to the unprecedented development of transport and communications that have reduced material production costs and permitted companies to be in close and permanent contact. Moreover, the author tries to demonstrate that contemporary economic globalization, in the same respect, is less integrated and interconnected, therefore more limited, than many could realize. Those limits influence important aspects of economic life and especially the economic environments in different countries, regardless of the characteristics and level of development. Factors such as economic gaps between nations, poverty and inequality, international migration and the new protectionism could, and most probably will, have an important impact upon the shape and pace of the economic globalization phenomenon. Realities such as different economic standards for North and South, fragmentary character of protectionism, intense fluctuations of international remittances remain as essential arguments supporting this idea.
\end{abstract}

Keywords: viable globalization, economic gaps, economic inequality, poverty, migration, new protectionism.

JEL Clasiffication: F60, I30, F13

\section{Introduction}

For a long time, the literature has used in tandem, as if it had the same meaning, two terms, namely: mundialization and globalization (Ortiz, 2006). If we ignore the semantic content of these two terms, we find, however, that they cannot be put entirely on the same plane. Thus, the world economy has been talked about for a very long time. If we consider the historical

Cite as:

Postelnicu, C., 2021. Economic Globalization between Expansion and Limits. Some Conceptual Considerations. Oradea Journal of Business and Economics, 6(1), pp. 21-32. http://doi.org/10.47535/19910jbe118 
context, it can be said that mundialization has its roots in the process of forming the nation states. As a result, an intense exchange of goods (not capital) has taken place worldwide over many decades (if not centuries), not being a recent human invention. In this article we prefer to use the term economic globalization, because it indicates more precisely a process typical of the years that marked the modern history of mankind. In our opinion, in essence, this phenomenon now called globalization differs from all previous forms of mundialization. Therefore, the difference is not only linguistic, but reaches much deeper sides.

In this regard, at least two questions hold our attention, as a conceptual approach. The first of these refers to the dynamics of globalization. Indeed, can we say that, at the moment, the process of economic globalization is over, or not? If we consider that economic globalization has gone through several phases or stages in a relatively short period of time, the answer should be no. The events that have marked the last decades show us that we are facing a process in full swing, therefore, still unfinished. What we do not know is how it will evolve in the short, medium and long term. However, we must expect radical transformations and mutations on a global scale, the nature of which is difficult to define today. For the time being, we must note that, at present, large geographical areas continue to be located, partially or almost entirely, outside the actual economic globalization, the population of these areas continuing to suffer from malnutrition, disease, ignorance, isolation and poverty. For the inhabitants of these regions, the notion of a globalized market is nothing more than an enigma. They helplessly witness the depletion of their natural resources and the degradation of the environment on which their very existence ultimately depends.

The second question could be summarized as follows: under these conditions, to what extent is economic globalization (as we now know it) viable in the longer run, or on the contrary, has obvious limits that it will not be able to overcome? Specifically, to what extent will certain risk factors limit in the near future its ability to cover all the states of the world, so as to flatten the huge economic gaps, which actually show the visible tendency to deepen? It is on these two aspects that we want to dwell in the present study, in the desire to form a clearer (not necessarily exhaustive) picture of the future of this controversial phenomenon called by most economic analysts as globalization. Before exposing our own point of view, let's take a brief look at a part of the literature dedicated to this vast subject, without being able to capture by far the contribution of all known authors. Of course, we cannot propose an exhaustive approach to the methodology of the dynamics of economic globalization, given the fact that this issue is not sufficiently clarified in the specialized literature. Instead, we aim to highlight some of the limits of economic globalization.

\section{A literature review}

The views expressed by some economists (Thomson \& Reuveny, 2009: 79-95) converge on the fact that economic globalization has created, over time, winners and losers. As such, one of the causes proved to be precisely the asymmetry of the development of the North and South of our planet, asymmetry materialized by a huge economic gap that has deepened continuously, now gaining sharp accents by dividing the world into rich and poor. This global divergence eventually led to profound implications for human development and security. Because of this, it is obvious that economic globalization will know certain limits that will soon be impossible to cross. The so-called benefits of this phenomenon, considered inevitable, however, have been drastically diminished by the inequality of opportunities that, lately, have acquired grotesque proportions.

Another resource in the field (Rieger \& Leibfried, 2003), which also has a suggestive title, puts a special emphasis on what the authors call non-economic preconditions of the phenomenon of globalization. Among them are highlighted, first of all, the cultural differences of different peoples that, despite all efforts, globalization will not be able to 
annihilate too soon. Or, precisely these differences can positively or negatively influence the forms of manifestation that globalization will cover, as well as its dynamics. In turn, another specialist (Chorafas, 2009) analyzes in detail the limiting framework of protectionism and economic nationalism on the process of globalization, stating for this purpose the case of Eurozone. Global financial crises, the author considers, are indisputable proof that globalization has obvious limits, in the sense that it cannot foresee or avoid them. A similar view on this subject is expressed by other authors (Boyer \& Drache [eds.], 1996), who argue that globalization threatens (slows) the role of the nation-state in the independent determination of its domestic policy, as a result of increasing dependence by the foreign market. However, they recognize that there are a significant number of options and alternatives (Boyer \& Drache [eds.], 1996: 23, 30, 263) available to governments to protect themselves from the adverse effects of the global economic cycle, thus leaving room for a more optimistic view of the future of globalization.

A topic much debated in the literature is that of convergence. Indeed, the problem of economic convergence cannot be separated from the phenomenon of globalization which, in various ways, encourages this process. It is precisely on this aspect that an ambitious study (Guillen, 2010) draws our attention, which tries to accurately dissect the problem of convergence against the background of more and more pronounced globalization. According to the author, globalization has allowed the diversification of economic actions rather than their convergence, especially in the newly industrialized states (Guillen, 2010: Chapter 1). Given the diverse views expressed on the impact of globalization on economic and social life, with a particular focus on the downsides, ranging from disaster to the idea of deglobalizing the economy, many researchers have begun to look for alternatives to the limits of this phenomenon considered irreversible. In this context, we cannot ignore the contributions of two other researchers who, in an interesting study (Cavanagh \& Mander, 2004) emphasize the idea of the existence of solutions to solve thorny problems generated by globalization. They believe that the pessimism of some researchers about the future of globalization stems from the "uncertainty and revolt of poor countries against rich nations" (Cavanagh \& Mander, 2004: XI). In the end, it all comes down to the question: "If you're not for globalization, then what are you for?" (Cavanagh \& Mander, 2004: XII).

Other researchers (Boulle, 2009) consider that opponents of globalization are in fact critical of the market economy (Boulle, 2009: 237). Or, the market economy has its objective laws that cannot be ignored by anyone. As a result, the author launches a real plea for the beneficial effects of globalization, even if some of its limitations have been visible for a long time and can no longer be challenged. In this regard, he refers to some critics who blame the World Trade Organization (WTO) which, through its policies, promotes "a transfer of risks to less developed countries", when we consider the deterioration of the environment and the depletion of natural resources (Boulle, 2009: 252). At the same time, the author wants to emphasize that there are many other factors that contribute to the deterioration of the natural environment, which are difficult to measure and which cannot necessarily be attributed to globalization (Boulle, 2009: 252).

Many other works are included in this line, which cannot be omitted from the bibliography dedicated to this subject. For example, we will mention just a few that we consider just as important. Among others, we refer to Jagdish Bhagwati (Bhagwati, 2004), John H. Dunning (Dunning, 2003), then the works of Nobel Laureate in Economics Joseph Stiglitz (Stiglitz, 2003; Stiglitz, 2006) and Robert Gilpin (Gilpin, 2000).

As for Joseph Stiglitz, he never stopped drawing attention to the fact that globalization has created its own brakes and limits in the way of its continuous expansion. One of these (perhaps the strongest) is the unacceptably high economic inequality both within societies and between nations (Stiglitz, 2015). Although the author refers to American society, the conclusions he draws are perfectly valid for the entire global economy, since, as the 
researcher argues, "economic inequality has become global" (Stiglitz, 2015, 114 et seq.). Joseph Stiglitz's work was not just a singular voice. It was preceded by another volume signed by the same author (Stiglitz, 2013). This time, Joseph Stiglitz treats economic inequality as a counterpart to the "laissez-faire" theory that has failed to solve some of the vital problems raised by contemporary globalization.

The well-known economist Thomas Piketty (Piketty, 2014; Piketty, 2015) speaks on the same topic in two representative volumes for the profile literature. In the first volume (Piketty, 2014), the author draws attention to the fact that the evolution of inequality, as a result of the concentration of wealth globally, endangers the very process of economic growth, turning into a brake (limit) on the path to globalization. Since "the rate of return on capital exceeds the rate of growth", the mechanism will be blocked "generating unsustainability" (Piketty, 2014: 1). Following very closely the evolution of economic inequality over time, in the second volume (Piketty, 2015), the author concludes that globalization has failed to resolve the conflict between capital and labor, further amplifying it. An edifying example is the problem of unemployment, which the author treats as a "social fracture" (Piketty, 2015: 4).

Two other researchers are trying to meet these problems (Acemoglu \& Robinson, 2012). They also come to the conclusion that certain theories of economic development no longer work under the pressure of the new wave of globalization. Not coincidentally, the authors point out that poor countries are in this situation not because of their geographical position or culture, or because their political leaders do not know which strategies to choose, but others must be the causes (Acemoglu \& Robinson, 2012: 45 et seq.), alluding to the forms of manifestation of globalization.

Other authors also consider economic inequality the main negative effect of globalization. We refer, among others, to Branko Mihailovic (Mihailovic, 2016) and Anthony B. Atkinson (Atkinson, 2015). Rodrik Dani (Dani, 2012) is on the same topic. The author criticizes in a nuanced and rigorous form all those who are still enthusiastic about the benefits of globalization. It is noteworthy that opinions on the limits of economic globalization are found in other studies (Sabatini, 2009), which show that the process of globalization, even in conditions of potentially beneficial economic changes, can lead to irreversible negative phenomena, if those changes triggers too fast.

Our brief foray into the literature, with the dominant theme of the limits of economic globalization, strengthens our belief that not all researchers rushed to applaud the "positive effects" of this phenomenon. On the contrary, weighed against the negative effects, it turns out that economic globalization has indisputable limits that can call into question its future. After all, it all comes down to the potential of globalization to ensure a decent and satisfying standard of living for the world's population.

\section{Viability of globalization and the main associated risk factors}

From the outset, the above title obliges us to answer seemingly simple questions, but with unsuspected consequences for the near or distant future, namely: is globalization viable in the medium and long term, given the presence of major risk factors, which have so far imprinted a discontinuous and fluctuating character on it? In other words, can we expect this phenomenon to continue indefinitely in a finite world? Here are just a few questions that fit into the architecture of the most important current issues.

In general, it is difficult to compile a complete inventory of the causes and factors that have given economic globalization a discontinuous character, marked by numerous crises accompanied by unmanageable deglobalizing effects. The scientific debates so far have focused more on how we can determine the degree (level) of globalization and less on its viability over time. Although a number of indicators such as the evolution of world trade, the distribution of foreign direct investment, the level of labor productivity, the degree (index) of 
human development and others clearly showed that the process of economic globalization is not progressing smoothly without major syncopes, the current of optimistic thinking in specialized studies continued to predominate, based on the phrase "inevitability" and "irreversibility" of this phenomenon (see, for example, Fairclough, 2009). It is true that, at the same time, there have been voices questioning this globalist view that economic globalization is constantly expanding (Goldblatt et al., 1999). The mentioned authors claim that there are enough arguments to consider that there are many exaggerations in the definition of economic globalization (Goldblatt et al., 1999: 1-31). The same argument is made by other researchers (Hirst et al., 1999). Although they adopt a moderate skepticism, they emphasize that the world economy is still far from the truly global stage (Hirst et al., 1999: 28).

Based on these findings, at least four risk factors can be identified that are holding back the process of globalization, marking its inevitable limits and calling into question its future viability. We consider, first of all, the economic gap between the so-called "North and South", then, secondly, the poverty and inequality in which hundreds of millions of people are struggling all over the planet, thirdly, migratory flows increasingly difficult to control and last but not least the "new protectionism" promoted by highly industrialized states.

As for the economic gap between North and South, this is not a novelty in the current international landscape. It was reported a long time ago, without a suitable solution. Over time, outstanding economists (Thomson \& Reuveny, 2009: 35 et seq.) have referred extensively to the issue of the asymmetry of the economic development of our planet's North and South and its implications for the globalization process.

Usually, it is difficult to draw a dividing line between the so-called "Global North" and "Global South" (Thomson \& Reuveny, 2009: 34) based on the level of economic development. The phrases "first world", "second world" and even "third world" have long been used in the specialized literature. Even today they can be found in some studies (Sajed, 2020). Judging as a whole, the use of such phrases has led, not infrequently, to erroneous or even denigrating conclusions, if we consider the contribution of many states, unjustly included in the above-mentioned groups, to the enrichment of world cultural heritage. It is true that, more recently, in many profile studies this error has been corrected, stating that by "second world" we must mean developing countries, the names used before being considered somewhat outdated (Harris et al., 2009). However, geographically, the whole of Africa (except the Republic of South Africa), Latin America (again with some exceptions), Central America (excluding Mexico) and a number of other states form South-East Asia are considered to be part of the "Global South" (deducted based on Roser \& OurWorldinData, 2019). As it is easy to notice, not even some of the most prestigious publications manage to make an absolutely clear delimitation between North and South, of course from an economic point of view.

The division of the economic world between North and South was first made in public by former German Chancellor Willy Brandt in a famous report (Brandt, 1980). Subsequently, for greater accuracy, specialists resorted to the use of the so-called "Brandt Line" still valid today (Codrington, 2005: 90). It should be noted, however, that this line also continues to be challenged especially by some developing countries (some of them considered emerging economies), on the grounds that it corresponds less and less to reality, the international framework being in a permanent change (Ollie, 2016). What is certain is that the industrialized North is home to all members of the G8 group and no less than four out of five permanent members of the United Nations Security Council.

In economic terms, this bipolarity hides a much deeper reality. Indeed, according to some sources (Oluwafemi, 2012: 47), 1/4 of the world's population controls $4 / 5$ of the income earned everywhere in the world. Also, $90 \%$ of the manufacturing industry is located in the northern hemisphere. Accordingly, 3/4 of the so-called South's population has access to 
only $1 / 5$ of world GDP. If the northern part of the Earth is home to about 1.2 billion people, or $23 \%$ of the world's total population, they provide $84 \%$ of the global gross domestic product. This is the result of the fact that about $20 \%$ of the population of rich countries consume $80 \%$ of the planet's natural resources. Despite the fact that the growth rates of real gross domestic product have been higher year-by-year in all emerging and developing countries than in developed economies (World Bank ${ }^{a}, 2016$ : 4), net income per capita in poor, southern countries, has become 19 times lower than in rich countries. To this was added the effect of the terrible social polarization, so that, in recent years, the top of the richest $1 \%$ of people in the world has reached, in recent years, a rate of accumulation of wealth twice as high as $50 \%$ of the world's poorest inhabitants, over the past 40 years (Facundo et al. [eds.], 2018: 11). The same idea is signaled by the report presented by Oxfam International (Oxfam, 2016: 4), which states that instead of creating a global economy that works for the prosperity of the majority, as for future generations, we have created an economy that works for the $1 \%$, wondering how such a thing was possible and why? Of course, this was also a veiled allusion to the inability of globalization to solve this crucial problem. So, given the intensification of the globalization process over the last two decades, the process of global redistribution has not worked. Otherwise, it would not have been possible for 2150 millionaires in dollars listed for 2019 to hold together a cumulative fortune greater than that of 4.6 billion people, many of them being among the poorest inhabitants of the planet, and the cumulative wealth of the 22 richest men on the planet to be greater than that of all women in Africa (Oxfam, 2020: 8).

The bipolarity of the economy (North-South) is not an exclusive creation of globalization. First of all, colonialism contributed to its emergence. Globalization has taken it on its way and amplified it, without succeeding in closing the economic gaps. On the contrary, as we mentioned before, they have become more and more threatening over the years. Moreover, economic inequality and poverty are the side effects of the asymmetry of the development of the rich North and the poor South. Although some specialized reports show that, over the years, extreme global poverty has been reduced recently, it is far from being eradicated, and the period of the international medical crisis in 2020 has led to the fall of new categories of people into extreme poverty (World Bank, 2020: xi). Thus, according to the report presented by the World Bank for 2020 (World Bank, 2020: 5), the medical crisis and climate effects have led to the reversal of trends in eradicating extreme poverty for the first time in recent years. At the same time, about $9.2 \%$ of the world's population is estimated to still live below the international poverty line at $\$ 1.9$ per person per day (World Bank, 2020: 28). Extreme poverty continues to persist, especially among the rural population, youth, people with poor education, the unemployed and especially children, the goal of completely eradicating poverty by 2030 being increasingly uncertain (World Bank, 2020: 36).

Despite the so-called progress made, based upon the background of the globalization process, extreme poverty is at unacceptably high levels, especially in Africa, but also in other geographical areas of Southeast Asia and Latin America (World Bank, 2020: 47 et seq.). It should be noted that even in some countries such as China, India, Indonesia, Brazil and others, where absolute poverty has decreased, relative inequality has increased in terms of polarization of internal poverty (see also World Bank, 2020: 110). Some of the causes that led to this situation are also described by the World Bank in its report for 2017 (World Bank ${ }^{a}$, 2017), namely: the implementation of insufficiently substantiated or even wrong economic reforms, the application of redistributive policies based on clientelism (World Bank ${ }^{\mathrm{a}}, 2017: 61$ ), the inability to fight corruption and organized crime and others.

Some economists (Hickel, 2017) are surprised that there are other researchers who are quick to say that in the last 30 years poverty has been halved, and by 2030 it will be eradicated (Hickel, 2017: 2). In fact, says the author, since 1960 until today the income gap between North and South has tripled, $60 \%$ of the world's population (i.e., no less than 4.3 
billion people) live on less than $\$ 5$ a day (Hickel, 2017: 2). We are told that poverty is a natural phenomenon when, in fact, it is a political problem, being in fact created. The author goes on to say that poor countries are in this situation because they are in fact integrated into a global economic system in conditions of inequality (Hickel, 2017: 3). Of course, when referring to the reduction of extreme poverty, Hickel considers some specialized reports issued by international economic organizations (United Nations, 2012), which stated that extreme poverty was declining in all regions (United Nations, 2012: 6), and the eradication of extreme poverty and hunger were considered as priorities.

As mentioned in the previous pages, the third risk factor for the viability of globalization is economic migration. According to data reported by international economic organizations (IOM, 2020: 10), in recent years the number of international economic migrants has continued to grow rapidly, reaching a total of 272 million people in 2019, compared to 150 million in 2000 , reaching $3.5 \%$ of the total world population, - that is, the 30th person today is a migrant. It is also interesting that global remittances have reached a total value of $\$ 689$ billion (IOM, 2020: 10), which, cumulatively, can already have a significant influence on the business environment, both in the countries of origin as well as in the host ones. The destinations of most migrants were Europe, regions of Asia and North America. Overall, since 2015 , no less than $2 / 3$ (ie $67 \%$ ) of total international migrants were concentrated in only 20 states, usually developed economies (United Nations, 2015: 1). As expected, most migrants came from underdeveloped countries.

What do the numbers above show? First of all, it is clear that, in the conditions of increasing interdependencies of the states determined by globalization, the migration of the population for purely economic reasons has become a reality that can no longer be overlooked. Secondly, this type of migration is a symbol and at the same time a consequence of global poverty. Third, despite the so-called benefits of labor migration (for example, the 251 million migrants in 2015, mostly from developing countries, sent home $\$ 441$ billion, according to international organizations (World Bank ${ }^{\mathrm{b}}, 2016$ : VII and XI)), they remain among the most vulnerable members of society. So far, globalization has failed to solve this problem either. On the contrary, it amplified it. Because of this, cross-border migration remains a hot topic for both underdeveloped and developed countries, and is a serious obstacle to advancing the process itself. The situation is also complicated by the fact that remittance flows have fluctuated significantly in recent years (World Bank $\left.{ }^{b}, 2017: 1\right)$. Even in the case of a possible stabilization of these flows, the discrepancy between the total amount of remittances leading to developing countries and the contribution of all economic migrants to the creation of the global gross domestic product is huge. Thus, according to data published in recent years by specialized institutions (McKinsey, 2016: 55), only in 2015, migrants contributed with 9.4\% to the creation of global gross domestic product, which at that time, in absolute terms, represented $\$ 6.7$ trillion. $90 \%$ of this amount has been appropriated by developed economies (McKinsey, 2016: 56). The current period, dominated by the medical crisis, brings with it a somewhat unique situation in the international economic landscape. It is already known that remittance flows tend to increase as developing countries (destinations of these flows) go through periods when economic difficulties intensify (Takenaka et al., 2020: 2). However, the pandemic period tends to worsen, at the same time, both the situation in the countries of adoption of migrants and those of origin (Takenaka et al., 2020: 2 ), being likely to produce real shock waves, in economic terms, in all layers of the global economy.

Finally, another obstacle to economic globalization is the new protectionism. It could be said that this current is nothing more than a way to return to the growing role of the state in the economy. In reality, we consider that the new protectionism is a reaction to the effects of unrestricted globalization (see also Ghemawat, 2017). Against the background of an intensive process of globalization, centrifugal trends promoted by both developing countries 
and heavily industrialized countries have begun to emerge. These trends are reflected in the implementation of alternative solutions designed to protect national interests. In the context of the succession of so many events caused by global economic crises, many states feel threatened. Globalization does not directly guarantee their security as long as great uncertainties as well as economic imbalances persist. At the same time, the trend towards protectionism is fueled by the inability of globalization to increase the resilience of national economies to the shocks caused by economic crises. Global rivalries have not disappeared, nor has unfair competition. As a result, the movement of the factors of production was largely uncontrollable, which gave protectionism a fragmentary character, manifested in different forms and intensities from one country to another. On the other hand, limitless globalization has ultimately led to the erosion of many global economic arrangements that are currently being cracked down by new protectionist measures. Some developed countries no longer want to share their very high level of science and technology with others, and developing (possibly poor) countries want to protect their natural resources that they still have.

The World Trade Organization has taken many initiatives over the years to encourage multilateral negotiations and arbitrate economic disputes. However, there are still many obstacles to free trade, some in sight, others more difficult to detect when it comes to non-tariff barriers, different quality standards, subsidies to producers, restrictive import quotas, hidden forms of dumping, consensual arrangements which usually also contain clauses or arrangements. Many of these issues have been reported by some researchers several years ago, anticipating their actual proportions (Hughes \& Krueger et al., 1984: 389-484; Baldwin, 1982: 263-292; Lang \& Hines, 1993).

\section{Conclusions}

The proliferation of the protectionist current does not mean the end of globalization. As a result, isolationism does not justify its forms of manifestation in an increasingly interdependent and economically interconnected world. However, lately, we have seen an unprecedented increase in resistance to globalization, as the risks to it become increasingly threatening. The severe criticisms leveled at it were amplified due to the fact that, in its development, this phenomenon was not accompanied by the expected positive results. Thus, globalization has gradually become a topic much debated by many researchers. The views expressed have been and continue to be extremely diverse, ranging from the exaggeration of benefits, to more radical interpretations that current globalization is nothing more than the modern version of colonialism. Viewed from a historical perspective, globalization has known several phases or stages, each with its pros and cons. The disadvantages have always been translated by certain limits, which are, in turn, the result of a field of objective forces that have slowed the trend of expansion in the territory. For example, the upper limit would be marked by the time when governments would be completely deprived of their ability to intervene in the market. Such a point has not yet been reached and will not be reached in the near future. Globalization has failed to penetrate very wide geographical areas, on the map of the world economy continuing to persist large white spots, where the degree of integration into the global market is almost insignificant. Therefore, the limits reported in this article are seen in terms of the potential of globalization to reduce the negative effects and ensure access to development for all economic actors, as defined by the United Nations (United Nations, 1987). For the time being, if the current risk factors reported by us persist and amplify, then economic globalization will not be viable in the long run, in the sense that, sooner or later, its expansion will be blocked. After all, the dynamics of this process must be seen in the light of factors favorable or unfavorable to 
globalization. In our opinion, the limitations analyzed in this article tend to tip the scales in favor of the limiting factors of this phenomenon. Consequently, in the near future, we should expect a slowdown in its evolution as a whole. The result is that only a globalization that encourages, in many forms, the economic development of all states can overcome the current limits and constraints.

\section{References}

Acemoglu, D., Robinson, J., 2012. Why Nations Fail: The Origins of Power, Prosperity and Poverty, New York: The Crown Publishing Group.

Atkinson, A. B., 2015. Inequality: What Can Be Done?, Cambridge, USA: Harvard University Press,.

Baldwin, Robert E., 1982. The Political Economy of Protectionism, in Bhagwati, Jagdish N. (ed.), Import Competition and Response, University of Chicago Press, available at: https://www.nber.org/system/files/chapters/c6008/c6008.pdf [Accessed 18 December 2020]. https://doi.org/10.7208/chicago/9780226045405.001.0001

Bhagwati, Jagdish, 2004. In Defense of Globalization, Oxford University Press.

Boulle, L., 2009. The Law of Globalization: An Introduction, The Netherlands: Kluwer Law International.

Boyer, R., Drache, D. eds., 1996. States Against Markets: The Limits of Globalization, Governance and Change in the Global Era, New York: Routledge. https://doi.org/10.4324/9780203982846.

Brandt, Willy, 1980. North-South: A Programme for Survival, The Report of the Independent Commission on International Development Issues, Pan World Affairs Books, MIT Press.

Cavanagh, John, Mander, Jerry (eds.), 2004. Alternatives to Economic Globalization: A Better World is Possible, Second Edition, San Francisco, California: Berrett-Koehler Publishers, Inc.

Chorafas, D. N., 2009. Globalization's Limits: Conflicting National Interests in Trade and Finance, 1st Edition, New York: Routledge,. https://doi.org/10.4324/9781315585161.

Codrington, Stephen, 2005. Planet Geography, Sidney: Solid Star Press.

Dani, R., 2012. Globalization Paradox: Democracy and the Future of the World Economy, New York: W. W. Norton \& Company, Inc.

Dunning, J. H., 2003. Making Globalization Good: The Moral Challenges of Global Capitalism, Oxford University Press. https://doi.org/10.1093/0199257019.001.0001

Facundo, A., Chancel, L., Piketty, Th., Saez, E., Zucman, G. (eds.), 2018. World Inequality

Report 2018, World Inequality Lab, available at:

https://wir2018.wid.world/files/download/wir2018-full-report-english.pdf [Accessed 18

December 2020]. https://doi.org/10.4159/9780674984769

Fairclough, N., 2009, Language and Globalization, Semiotica Journal, Volume 2009: Issue 173, 1/4, 12 Feb. 2009. https://doi.org/10.1515/SEMI.2009.014

Ghemawat, Pankaj, 2017. Globalization in the Age of Trump. Protectionism will change how companies do business_but not in the ways you think, Harvard Business Review, July-August 2017 Magazine, available at: https://hbr.org/2017/07/globalization-in-the-age-of-trump [Accessed 10 December 2020].

Gilpin, R., 2000. The Challenge of Global Capitalism: The World Economy in the 21st Century, Princeton University Press.

Goldblatt, D., Perraton, J., Held, D., McGrew, A., 1999. Global Transformations: Politics, Economics and Culture, Cambridge: Polity Press.

Guillen, Mauro F., 2010. The Limits of Convergence: Globalization and Organizational Change in Argentina, South Korea and Spain, Princeton: Princeton University Press. 
Harris, D., Moore, M., Schmitz, H., 2009. Country Classifications for a Changing World, Working Paper volume 2009, number 326, May 2009, Centre for the Future State, IDS Institute of Development Studies, University of Sussex, Brighton, UK, available at: https://assets.publishing.service.gov.uk/media/57a08b65ed915d3cfd000cc4/Wp326.pdf [Accessed 08 December 2020]. https://doi.org/10.1111/i.2040-0209.2009.00326 2.x Hickel, J., 2017. The Divide: A Brief Guide to Global Inequality and Its Solutions, London: William Heinemann.

Hirst, P., Thompson G., Bromley, S., 1999. Globalization in Question, 3rd Edition, , Cambridge, UK: Polity Press.

Hughes, H., Krueger, A. O., 1984. Effects of Protection in Developed Countries on Developing Countries' Export of Manufactures, in Baldwin, Robert E., Krueger, Anne O. (eds.), The Structure and Evolution of Recent U.S. Trade Policy, University of Chicago Press, available at: https://www.nber.org/system/files/chapters/c5842/c5842.pdf [Accessed 08 December 2020].

IOM - International Organization for Migration, 2020. World Migration Report 2020, United Nations Publications, Geneva, Switzerland, available at: https://www.un.org/sites/un2.un.org/files/wmr 2020.pdf [Accessed 08 December 2020]. Lang, T., Hines, C., 1993. The New Protectionism: Protecting the Future Against Free Trade, Earthscan Ltd.

McKinsey Global Institute, 2016. People on the Move: Global Migration's Impact and Opportunity, McKinsey \& Company, December 2016, available at: https://www.mckinsey.com/ /media/McKinsey/Industries/Public\%20and\%20Social\%20Sec tor/Our\%20Insights/Global\%20migrations\%20impact\%20and\%20opportunity/MGl-Peopleon-the-Move-Full-report.pdf [Accessed 10 December 2020].

Mihailovic, B., 2016. Global Inequality: A New Approach for Age of Globalization, Cambridge, USA: Harvard University Press,.

Ollie, Tait, 2016. The North-South Divide: How Do We Measure Development Around the World? To What Extent is the Brandt Line Outdated?, King Edward VI School, Southampton Resources, available at: https://intranet.kes.hants.sch.uk/resource.aspx?id=145038 [Accessed 10 December 2020].

Oluwafemi, Mimiko Nahzeem, 2012. Globalization: The Politics of Global Economic Relations and International Business, Durham, N.C.: Carolina Academic Press.

Ortiz, R., 2006. Mundialization/Globalization, Theory Culture \& Society Journal, Vol.23(2-3), Sage Publications. https://doi.org/10.1177/026327640602300270

Oxfam International, 2016. An Economy for the 1\%, 210 Oxfam Briefing Paper 18 January 2016, available

https://www-cdn.oxfam.org/s3fs-public/file attachments/bp210-economy-one-percent-tax-h avens-180116-en 0.pdf [Accessed 08 December 2020]

Oxfam International, 2020. Time to Care. Unpaid and Underpaid Care Work and the Global Inequality Crisis, Oxfam Briefing Paper January 2020, available at: https://oxfamilibrary.openrepository.com/bitstream/handle/10546/620928/bp-time-to-care-i nequality-200120-en.pdf [Accessed 08 December 2020]

Piketty, Th., 2014. Capital in the Twenty-First Century, USA: Harvard University Press. https://doi.org/10.4159/9780674369542

Piketty, Th., 2015. Economics of Inequality, USA: Harvard University Press. https://doi.org/10.4159/9780674915565

Rieger, E., Leibfried, S., 2003. Limits to Globalization: Welfare States and World Economy, Cambridge: Polity Press.

Roser, M., OurWorldinData Charts, 2019. Human Development Index (HDI), available at: https://ourworldindata.org/human-development-index [Accessed 08 December 2020] 
Sabatini, G., 2009. I limiti della globalizzazione: ipotesi per la sua regolazione, Milano: Ed. Franco Angeli.

Sajed, A., 2020. From the Third World to the Global South, E-International Relations, July 27, 2020, available at: https://www.e-ir.info/2020/07/27/from-the-third-world-to-the-global-south/_[Accessed 07 December 2020]

Stiglitz, J., 2003. Globalization and Its Discontents, W.W. Norton \& Company, New York. Stiglitz, J., 2006. Making Globalization Work, First Edition, New York: W. W. Norton \& Company.

Stiglitz, J., 2013. The Price of Inequality: How Today's Divided Society Endagers Our Future, New York: W. W. Norton \& Company.

Stiglitz, J., 2015. The Great Divide: Unequal Societies and What We Can Do About Them, New York: W. W. Norton \& Company.

Takenaka, Aiko Kikkawa, Villafuerte, James, Gaspar, Raymond, Narayanan, Badri, 2020. COVID-19 Impact on International Migration, Remittances, and Recipient Households in Developing Asia, ADB Briefs, No. 148 / August 2020, Asian Development Bank, available at: https://www.adb.org/sites/default/files/publication/622796/covid-19-impact-migration-remitt ances-asia.pdf [Accessed 07 December 2020]. http://dx.doi.org/10.22617/BRF200219-2

Thomson, W. R., Reuveny, R., 2009. Limits to Globalization. North-South Divergence, 1st Edition, New York: Routledge. https://doi.org/10.4324/9780203872796

United Nations, 1987. Our Common Future, Report of the World Commission on Environment and Development, United Nations General Assembly, 04 August 1987, available at: https://digitallibrary.un.org/record/139811 [Accessed 07 December 2020]

United Nations, 2012. The Millenium Development Goals Report, United Nations Publications, New York, available at: http://mdgs.un.org/unsd/mdg/Resources/Static/Products/Progress2012/English2012.pdf

[Accessed 07 December 2020]

United Nations, 2016. International Migration Report 2015. Highlights, UN Department of Economic and Social Affairs, UN New York, available at: https://www.un.org/en/development/desa/population/migration/publications/migrationreport /docs/MigrationReport2015 Highlights.pdf [Accessed 07 December 2020]

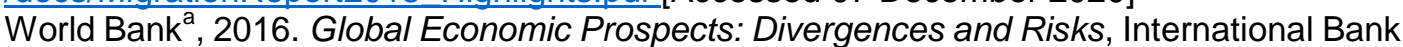
for Reconstruction and Development / The World Bank Group, Washington, D.C., available at:

http://pubdocs.worldbank.org/en/842861463605615468/Global-Economic-Prospects-June2016-Divergences-and-risks.pdf [Accessed $07 \quad$ December 2020 ]. https://doi.org/10.1596/978-1-4648-0777-0

World Bank ${ }^{\mathrm{b}}$, 2016. Migration and Remittances Factbook 2016, 3rd Edition, World Bank Group, Washington, D.C., available at: https://openknowledge.worldbank.org/bitstream/handle/10986/23743/9781464803192.pdf? $\begin{array}{lllll}\text { sequence }=3 \& \text { isAllowed }=y & \text { [Accessed } & 07 & \text { December } & 2020 \text { ]. }\end{array}$ https://doi.org/10.1596/978-1-4648-0319-2

World Bank ${ }^{\mathrm{a}}$, 2017, World Development Report 2017. Governance and the Law, International Bank for Reconstruction and Development / The World Bank Group, Washington, D.C., available at: https://www.worldbank.org/en/publication/wdr2017 [Accessed 07 December 2020]. https://doi.org/10.1596/978-1-4648-0950-7

World Bank ${ }^{\mathrm{b}}, 2017$, Remittances, Recent Developments and Outlook, Special Topic: Global Compact on Migration, World Bank Group \& Knomad, Migration and Development Brief 27, April 2017, available at: https://openknowledge.worldbank.org/bitstream/handle/10986/30278/BRI-PUBLIC-Knowle 
dge-Note-Add-Series-MigrationandDevelopmentBrief27-1. pdf? sequence $=1$ \&is Allowed $=y$ [Accessed 07 December 2020]

World Bank, 2020, Poverty and Shared Prosperity 2020. Reversals of Fortune, Washington, D.C.: International Bank for Reconstruction and Development / The World Bank Group,. available at: https://openknowledge.worldbank.org/bitstream/handle/10986/34496/9781464816024.pdf [Accessed 07 December 2020]. https://doi.org/10.1596/978-1-4648-1602-4

\section{Bio-Note}

Cătălin Postelnicu is associate professor, Ph.D., Faculty of Economic Studies and Business Administration, Babeș-Bolyai University in Cluj-Napoca, Romania. Fields of interest: International Economics, Economic Globalization, Multinational Corporations, Foreign Direct Investments. 